\title{
Losing Identity, Abandoning Values, and Alienating Self: The Impact of Immigration in Mohammed Abdul-Wali's They Die Strangers
}

\author{
Mohammed Albalawi
}

Ministry of Education, Saudi Arabia

Copyright (C) 2015 Horizon Research Publishing All rights reserved.

\begin{abstract}
This paper discusses the impact of immigration on individuals in the Yemeni novella, They Die Strangers. It argues that while émigrés seek spiritual or financial success, they lose identities and abandon values when attempting to become integrated into a new society. The paper rethinks the poor's plight in the novella and offers a unique portrayal through which people who are posed by social, political, and economic difficulties become deficient and disconnected.
\end{abstract}

Keywords Immigration, Arab, Literature, Yemen, Alienation, Values

\section{Introduction}

Mohammed Abdul-Wali was born in Ethiopia in 1940 to mixed race parents-his mother was Ethiopian and his father was an émigré from North Yemen. Before Abdul-Wali, particularly prior to 1960 s, Yemeni literature comprised primarily of histories, religious scholarship, and narratives that idealized the elites from the past. Works that are concerned with ordinary people were absent. Shelagh Weir notes that Abdul-Wali is considered "a pioneer of fiction writing" as his works marked " a radical break from...traditional genres by focusing on contemporary themes, and by describing with vivid and compassionate realism the lives of ordinary people, especially the oppressed and socially marginal." i His landmark work, They Die Strangers, as well as many of Abdul-Wali's stories, center on Yemenis abroad.ii The plight of émigrés in They Die Strangers is an interesting one. Not only does it pertain to all men and women who experience solitary lives in their own communities, but it also involves the struggle that the poor and marginalized undergo, which appeal to people's sense of humanity. The novella takes place in a critical period in Yemen's history during which the North Yemen Civil War (1962-1970) was fought. The trauma of war and its psychological and economical impacts on individuals constitute deeper dimensions to understand how one may end up virtually unknown in strange places despite the dreams and hopes of gaining any financial or spiritual success.

They Die Strangers tells the story of the protagonist Abdou Said who leaves his family in Yemen to seek work in a neighboring country, Ethiopia, in order to support them. He works hard as a storekeeper sending the money he earns to Yemen. In Ethiopia, Abdou emerges as a respected individual as people in the neighborhood treat him as one of them. Even though he appears as a devout Muslim who prays regularly and does not consume alcohol, Abdou engages in many adulterous relationships with prostitutes. Allegedly, he has an illegitimate child with one of the prostitutes whose death impacts his life. It may surprise some readers that Abdou chooses to seek work in a country that has been always considered as one of the poorest in the world. iii Frahan Mohammed states, "The idea of Ethiopia as a land of opportunity may strike some readers as strange, but clearly at that time it was just like that for some."iv Many Yemenis migrated to Ethiopia to escape poverty and oppression in their homeland and some of these émigrés married Ethiopian women and had children. These children were called muwallad (a child of mixed race).

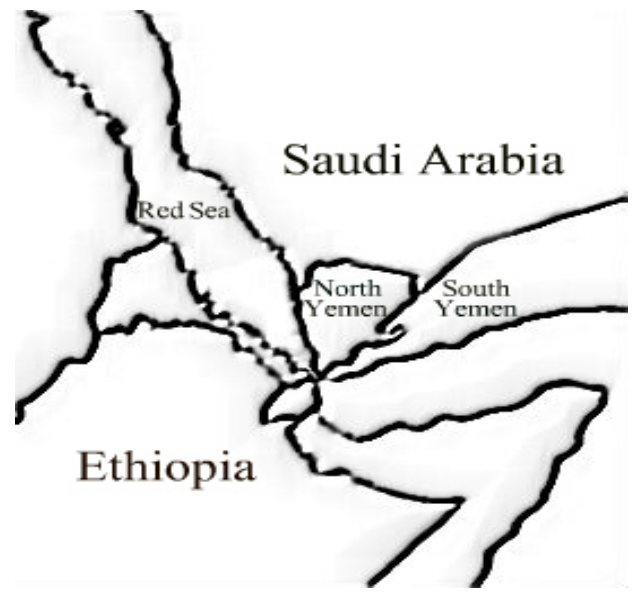

Figure 1. A map showing Yemen during the 1950s and 1960s. Before its unification in 1990, Yemen was divided into two countries, South Yemen, and North Yemen where the civil war started driving thousands to migrate. 


\section{Alienation and Sexuality in They Die Strangers}

They Die Strangers begins in Ethiopia's capital, Addis Ababa. The first few lines introduce the protagonist. Readers learn that Abdou owns a shop in a busy quarter in the city, Sodest Kilo (Kilo Six) and that he has been living there for ten years. He appears as a likeable person and the residents appreciate his existence because he always treats them kindly and never takes off the smile from his face. Abdou's expression is "a constant mask of affability"[17]. The population of Sodest Kilo consists of a binary world. Both rich people and poor live there. Through the dichotomy of Sodest Kilo into two worlds, the author shows the contradictions of Abdou's life. Yet, he does not care about this diverging life he is undergoing. Even though he literally interacts with the people, he is spiritually isolated. As the author writes, "he lives among them but apart, like the distance between his dirty black clothes and his smiling white face" [17]. Such a beautiful analogy the writer draws to show the solitary life one lives even if people surround him. The loneliness of his soul is embedded in his detachment from people whose presence is nothing but "dirty black clothes" that he is wearing.

The shop he owns is very small, but it is also his home in which he sleeps. Abdou spends his leisure time taking care of the garden he has at the back of his shop. The door that leads to his beautiful garden provides him with a spiritual access to an alternative world where he gets isolated from everyone. Lystad notes that alienation is "a sign of personal dissatisfaction" that is linked particularly to "economic and political elements." $v$ Abdou is not happy in Sodest Kilo because he is far from the people he loves. The war in his homeland that has led many to seek work elsewhere appears to have created this dissatisfaction. The author writes, "The yard was more organized and more beautiful than the area he called his room. A considerable amount of effort had gone into his yard..." [18]. It seems that Abdou finds remedy in his yard. His disorderly shop serves to symbolize his lack of interest in obtaining a sense of identity. Abdou does not put much effort into the shop because it is the place that enables him to interact with people. Abdou chooses to alienate himself because he feels he is different even if people love him. He does not belong to this place. The only thing he values is work because it is what has motivated him to come to Ethiopia in the first place.

The first major sign that Abdou's goal is at risk is when the narrator displays how excessively Abdou flirts with women when they are crowding the shop: "he'd find the time to wink at a beautiful woman or pinch a young girl's breast. He might even take delights in flirting with an old woman" [19]. Even though he is benevolent toward all, his hypersexuality toward women designates the axis around which his life in Ethiopia revolves. The shop gets overcrowded every day - a fact that has been troubling the Armenian-owned and well-equipped modern store on the outskirts of the quarter. The author obscures concepts of identity and belonging when showing Abdou's sexual exploits. While we come to recognize Abdou's alienation from his surroundings when he spends most of his time in his garden, the love affairs he has had may symbolize a sense of belonging to the place. Because he is separated from his family and because prostitutes linger near Sodest Kilo, Abdou has extramarital coitus. Robert Whitehurst explains that some married people engage in extramarital sex as a result of their alienation and opportunity factors. vi Despite his sexual encounters, Abdou fails to be part of the new society. Charles Hobart notes that alienation creates "a feeling that others don't understand" leads to "impaired ability to communicate with others."viiAlthough Abdou is physically among the people of Sodest Kilo, he is internally absent. Because Abdou has chosen not to confide in anyone, he appears as a ghost figure. It seems that the choice Abdou has made to keep his life ambiguous adds more depth to his failure of belonging. Abdou's reliance on masculinity rather than assimilation indicates his schizophrenic vision of his life in Ethiopia. While he is so entrenched in sex, Abdou emerges as a man who does not know how to fit in. He has learned however how to bring more money through pleasing women. Abdou presents a paradox. He never belongs even if he appears as a man whom women and children love.

\section{Abdou's Trauma}

After presenting Abdou as a mysterious figure in the eyes of people of Sodest Kilo, the narrator reveals the truth about Abdou's background:

As a boy, he had been a shepherd. He used to drink only the goat's milk, which he milked secretly in the cool mountain breeze. Perhaps he ate some fruit that grew on village trees or dates that grew in the valley...Abdou Said's treasured memories were of that valley, the trees ripe with fruit, goats lowing, These were the things he remembered when he chewed leaves of qat and a far-off expression came into his eyes.viii [25]

Through the above lines, readers are invited to perceive another side of Abdou. Abdou grew up in Yemen as a shepherd. Abdou never knew his mother because he was a child when an epidemic struck his village killing many people including his mother. The village faced many epidemics. He spent most of his childhood shepherding, but then he wasn't, Abdou went out with his father to "farm the terraces on the mountainside" [25]. Moreover, the narrator says, "He still remembered the bread his grandmother used to make, spiced with fenugreek seeds, how delicious the bread was with fenugreek pudding or sometimes with porridge with yoghurt and ghee in it. Those were the days" [25]. The recollections Abdou has from his childhood insinuate a deep nostalgic feeling for his life in Yemen. In Sodest Kilo, Abdou cherishes these moments from his past and never neglects this part of life even after spending years 
away from his homeland. Claude Fischer declares that alienation results as a separateness from something. ix Because Abdou left his family, the treasuring of his childhood memories appears to signal the sense of alienation Abdou has been feeling. But Abdou chooses to conceal these feelings about his childhood because he has never assimilated.

Abdou suffered two tragic losses in his childhood. Not only has Abdou never known his mother, but also he has lost his grandmother whose presence seemed to offer a sense of motherhood to him. The loss of both women is crucial to the construction of Abdou's upbringing. But the death of his grandmother is more central as Abdou recalls clearly the incident. In order to show the intensity of this memory, the narrator says:

He still remembered the sound of death rattling in her throat as she lay in a corner of her room, saying, "Son, I'll get over this quickly and be well again soon." But that wasn't to be. She died without saying a word, her throat constricted. He was asleep by her side; when he awake in the morning he felt her bony hands digging into his ribs. He had said to her, unwittingly, "Grandma, Grandma...you're hurting me." [25]

While Abdou has no recollection of his mother's passing, the death of his grandmother seems to have left a vivid mark on his life. It is no secret that the absence of motherhood affects a child's life. Dora Black, a child and adolescent psychiatrist, states, "for optimal emotional, social, and psychosexual development to occur, children need a warm, secure, affectionate, individualised, and continuous experience of care from a few caretakers who interact with them in a sensitive way and who can live in harmony with each other."x Abdou's grandmother appears to have soothed him for quite some time. But she knew that if she died, Abdou would be more vulnerable to life's cruelty even though his father was around. She knew that her presence was essential in Abdou's life. That was why her words "Son, I'll get over this quickly and be well again soon" were to offer a sense of assurance to Abdou. But Abdou was bereaved very early. Studies show that children who are bereaved early are more likely to have psychiatric problems in their life.xi

After these tragedies, Abdou got married at a very young age. He was fifteen, unaware of this practice that is common in rural and impoverished areas, where parents arrange these marriages, and boys and girls have no choice. About Abdou's marriage, the author writes that one day Abdou went to the market to buy some food and returned to his house to find a girl sitting in the corner of his house where he usually sits [25-26]. Early marriage, especially when it is accompanied by early first birth, makes a person more exposed to the shackles of life problems. Kristin Moore and Linda J. Waite assert, "the social and economic difficulties posed by the combination of early marriage plus parenthood are ...unlike those experienced by an older couple faced with an untimely pregnancy" [22]. Abdou's marriage made it very difficult for them to break out of the cycle of poverty. Abdou understands this fact later and that awareness leads him to leave Yemen. People in the village keep talking about an émigré who has sent a lot of money to his family in Yemen asking them to build a three-story residence for him. This news has spread almost to every wife in the village creating resentment among couples. The narrator describes this jealousy environment by writing that wives enviously say about the émigré, "I wish I were his wife" [26]. The belief that everyone who emigrated comes back rich has been well established in the village. This conviction makes Abdou wonders, "Why? Is money thrown in the streets there?" [26]. The words he hears about how émigrés manage to bring happiness to their families with the money they have made were "like a dagger piercing his heart" [26].

Abdou has tried to drown the feelings of incompetence because of the talks about the wealthy émigré. But he fails to hide them when his kid manages to make him omnipresent and immanent in reality. After the wealthy émigré has returned to his newly built house in Yemen, everyone in the village goes to see him, including the children. Abdou's son is among those who have gone to celebrate this occasion. When the son comes back, he shows his father some dates he has got from the wealthy man. The author describes this moment, "He showed them to his father and said, 'Look, Baba, he gave these to me.' As he nibbled at them, he added, 'Why don't you emigrate and bring me something like this?' [27]. From this instant, Abdou has felt the surge of desire to leave in order to support his family and to be able to give them what they need. The author writes that Abdou feels the "sharp pain in his heart" after hearing his son's words [27]. Abdou immediately goes to his father and tells him about his decision to leave:

"What about our land, Abdou?"

"You can take care of it."

"But I'm getting old."

"My wife will help you. I'll work there and send you money to hire men to help."

His father wanted him to stay, but he wanted him to emigrate, too. He was unable to decide. But Abdou Sai'd made up his own mind.

"Father, I'm waiting for your blessing"

"If you insist, I'll pray for you. May God take care of you, help you, and bring you success."[27]

The question of emigration is a tough one, not only on Abdou but also on his father. Research shows that migration causes changes to family and destabilizes family relations over time.xii Abdou's father expresses shock and confusion at his son's decision. Through the above lines, the author reveals beautifully juxtaposition between fear and desire. The father knows that, because of his old age, he would not be able to take care of the family's land. However, he doesn't want to stand in his son's way. Abdou realizes that his presence will lower his sense of self-worth. Therefore, in 
order to build his self-worth, Abdou feels it is necessary to emigrate and be estranged from his family. After revealing why Abdou has emigrated, the narrator jumps to the present. Now, it has been twelve years since Abdou left. Throughout those years, Abdou has known very little about his family from the letters that he receives twice or three times a year. Abdou gets happy when receiving a letter "despite the long periods of waiting" [27]. The letters bring happiness and enjoyment to Abdou. Whenever he opens a letter, he feels attached to his homeland, like he has never left. In order to show how Abdou is emotionally immersed into his beloved home, the narrator says, "in his heart, he live[s] not in Sodest Kilo, but in his faraway village in Yemen" [27].

Sometimes the letters break Abdou into tears of happiness. Psychologists say that crying tears of joy occurs by "responding to an overwhelmingly positive emotion with a negative one."xiii This incident happens in one letter Abdou received from home where pictures of his new house were included. The narrator states, "The new house was the village's bride, the letter said; it could be seen from a distance, it was beautiful. Tears streamed down Abdou Said's face..." [28]. Abdou is extremely happy that the money he has been sending helped build the house. However, he wishes he were home, among the people he loves to celebrate the new residence. In the same letter, Abdou is impressed at he sees his son's beautiful handwriting. The son, who was eight when his father left, is a grown man now. He is married and has a son of his own. The narrator says that Abdou feels "the distance in time and miles that separated him from his home. He became a grandfather and the owner of one of the most beautiful houses in the village" [28].

The subject of family in Abdou's story is a noteworthy one. While he jumps from one affair to the next, he values his family. It appears that the women in Sodest Kilo symbolize a temporary haven for Abdou. They bear a physical resemblance to his wife offering Abdou physical and emotional stability. He needs them as much they need him. His actions advocate his need of his family that he has been deprived of. Could the life in Yemen be any better, Abdou would have stayed? Now, he has missed many treasured moments - his son growing up, the building of this house, the birth of his grandson. Such beautiful moments drive fathers to intense happiness. Having his dream house built, he seems little interested in learning what the people would say if they know this news. Abdou hangs a photo of his house in the middle of the store and waits anxiously for anyone to ask him about the owner. The author writes that one day:

Abdou waited on his customers, tending to their orders, all the while following their eyes, which were fixed on the photo. Deep inside, he was anxious. What would they say if they knew this was his house, his own house? What sort of feelings would possess them? Were it not for modesty, he would have shown off the photo, but he couldn't. No one knew anything about him except that he smiled and waited on them. He never disclosed anything about himself or his dreams. He remained as silent as a tomb." [28]
Clearly, Abdou has alienated himself with his adherence to secrecy about his life. The author uses an interesting analogy to describe how Abdou has been a mysterious person in the eyes of people of Sodest Kilo. He is like a tomb to which people see, but are not able to know the story behind it. Now, it is different as Abdou feels he has accomplished his ultimate dream - getting a house for his family. Abdou's contradictory behavior emanates from his estrangement. William Holmes notes that alienation includes a contradiction in social conditions."xiv $\mathrm{He}$ is proud of his accomplishment and ardent to share this triumph with others. Not long enough until one asks him about the photo stating, "It's beautiful" [28]. This question unleashes Abdou's happiness that fills his heart. To show how Abdou is filled with contentment, the narrator says, "For the first time, he added extra flour to the kilo he handed the customer" [29]. It is a moment of pride for Abdou. However, Abdou confides in nobody. He tells the customer that the owner of the house is the chief of his tribe. For Abdou, it is enough that he knows the truth.

Because Abdou has only seen his house in pictures, it becomes an almost fanatical obsession to be in it. Abdou visions that he "prays every morning on the roof of his new house so that the village people could see him...[, he goes] to the garden to pick from his fruit... [and that people] would say, 'Whose house is this?' 'Oh! What a great house!'” [34]. It seems that Abdou seeks people's admiration of the beauty of his house to boost his self-worth as if nothing else is praiseworthy in his life. Abdou thinks he has defiled his beliefs and religion. He is not honored by his life in Ethiopia. In his classical fantasy, The Princess and Curdie, the Swedish novelists George MacDonald writes, "a beast does not know that he is a beast, and the nearer a man gets to being a beast, the less he knows it."xv Abdou is a beast in Sodest Kilo. The more he devours young women the more he becomes unaware of his wrong deeds. The words of one of his concubines support this analogy. After one intimate night, Abdou does not seem to show any kind of affection toward his lover who wrathfully says, "you're an animal with no heart and no taste. All you want is to screw like a dog" and later adds, "nothing concerns you, not even a woman in your arms. You quench your thirst. You live in a mirage, my friend, a mirage" [34]. But these harsh words have no effects on Abdou because he is callous. No matter what any lover says, Abdou feels indifferent. It is such a remarkable handling of the immigration issue by the author.

\section{Immigration, the Psychological Impact, and the Need for Redemption}

The transformation of Abdou's character from an ordinary farmer and shepherd into a beast with no remorse is attributed to the impact of immigration on individuals. The writer's approach to highlight the destructive impact of immigration on a person's character is very noteworthy. Chelala states, "In most immigration stories, the main 
character emigrates to a foreign land, works hard at success and finally reflects on his or her achievement. However, in Abdul-Wali's work, emigrants risk losing their identities and severing ties with their mother land without becoming integrated into the new society." xvi While Abdou has worked hard for many years, he has never amalgamated with others in Sodest Kilo. The absence of his family has left its mark on Abdou's sense of belonging. Had his father, wife, and son surrounded him, Abdou could have kept his values, or perhaps more importantly, his identity. So far, Abdou has only been concerned with making money. He has not felt any gratitude or warmth for anybody in Sodest Kilo, not even to a single mistress. His family and house, however, inspire feelings and emotions in him. Particularly, Abdou gets touched whenever the image of his house comes to his mind. But the struggle Abdou is experiencing in relation to his life in Sodest kilo starts to escalate as the novels reaches its climatic point: the death of a prostitute with whom he is accused of having an illegitimate child.

One evening while he is in his store, Ta'atto, one of his mistresses, pays Abdou a visit only to deliver the alarming news. A friend of her, Fatimah, has died leaving a son, supposedly to be Abdou's. In order to evoke Abdou's sympathy, she tells him that Fatimah has no family and the son is alone. She compassionately says, "He's your son, Abdou. You've got to do something for him. You must!" [35]. Abdou is puzzled, as he has "never before faced a problem like this" [36].

Abdou gets afraid that words may spread and reach his family, which would eventually break his family apart. Apparently, he needs to deal with this unexpected matter, but he does not know how. He realizes that if he accepts this child, many women would come and "throw their children" at him [36]. Hence, he contests Ta'atto's allegations saying, "I work very hard for my living, to earn a few coins. By God, how can you ask me to join a bastard to my name? Who knows if he's even mine? I can't do anything for you" [36]. Abdou is right. At that time - the late 1960s and early 1970s'-it was almost impossible to determine the biological father. The DNA paternity test was only introduced in the late 1970s and 1980s. xvii Therefore, Abdou makes it very clear to Ta'atto that he is not unwise so he acknowledges a child that nobody knows for sure who the father is. When Ta'atto criticizes Abdou of having no heart, he indignantly says one of the most significant lines in the novella:

I don't have a heart, huh? If only you knew how much I suffer, how I kill myself working. I own an honest business. I would like to live in my home again. I would like to die after I've done good things for my son and wife. No Ta'atto, you know nothing. First I'll go to Mekkah and perform the Hajj. All my sins will be forgiven. Then I'll return to my village. There I'll stay in the mosque, worshipping God day and night. God commands us, Ta'atto, to work as hard as we can, to work for our children, our legal children, But I have only one son. God created those others, and He will take care of them..."[37]

Abdou, for the first time in the novella, stands for himself. He does not remain silent any more because his whole dream might collapse. The emotion presented in this passage is intense. The fear of losing his family provokes Abdou to speak. He defends himself powerfully. Abdou knows that this child matter would lead to denigrating his image. Therefore, he feels the need to mediate and explain to Ta'atto who perhaps spreads the words to other women. Abdou's dismissive remarks weaken his zealous desire to be with his family, the only people he acknowledges in this world. The passage highlights the suffering of Abdou. He has been working mercilessly for over a decade in order to give his family a better life. This tremendous effort should not be wasted. Because he has a legitimate business, Abdou thinks his business environment has to be congruent with his own values. He could have lied or cheated his customers, but he has chosen integrity over greed. The image of the honest Abdou appears primarily here. The author draws the reader's attention to it very obviously in Abdou's remark: "I would like to die after I've done good things for my son and wife." It is apparent that these words symbolize Abdou's motto. He has strived so his family does not struggle after he is gone. Moreover, it is not enough for Abdou that he leaves the world after having his family financially settled, he also wants to devote the remaining years of his life to worshiping God. Because Hajj is believed in Islam to expiate all kinds of sins, whether major or minor, it comes no surprise that Abdou wants to perform it. xviii He sees himself as a person who has done some iniquitous deeds in Sodest Kilo. The adulterous life he has lived needs to be redeemed. Abdou feels he should not be held accountable for any illegitimate child. Abdou's confession does not appear to elicit any compassionate response on Ta'atto. $\mathrm{Au}$ contraire, it infuriates Ta'atto even more.

Ta'atto does not care about Abdou's plans. She requests an instant solution to what she thinks is the outcome of Abdou's countless affairs. She endeavors to persuade him to take in the child but when she fails, she slaps him on his face. Not only does Ta'atto insult Abdou, but also she threatens to tell others about how atrocious Abdou is. Ta'atto feels the need to expose this matter in the quarter-a move that would hopefully make Abdou changes his mind. Abdou has never been disgraced like this before. After Ta'atto has left, Abdou thinks intensely of what has just happened. She has successfully provoked strong emotions of both anger and disgust in him. A state of confusion clouds Abdou's mind. This is shown clearly in the way he deals with his first customer after Ta'atto left. When the customer asks for cigarettes and matches, Abdou shouts at him, "I'm all out" even though the cigarettes are right in front of the customer's eyes. The man seems baffled at Abdou reaction. Abdou is distraught over Ta'atto's insult. Sanjay Palshikar asserts that humiliation is "a deeply distressing experience...[which] one cannot get over easily." xix Losing customers seems acceptable for him now.

Ta'atto resorts to a wise man in the quarter, Sayyid Amin, 
in order to reveal the news and seek help as well. Amin is a Muslim in his fifties whom both Muslims and Christians frequently visit to solve their problems. Amin feels morally obliged to save the child. Amin is highly respected in Addis Ababa and widely believed to be a "pure spirit," whom angels come to visit frequently [42]. Such a reputation gives Amin a renowned position at which he can give commands that would be well followed. Using his religious standing, Amin asks another well-respected person and a community leader, Abdul Latif, to handle the problem. He tells Abdul Latif that God has chosen him for this job. Because he thinks God must love him for choosing him to carry this mission, Abdul Latif is not only enthusiastic to do the job, but also optimistic that he would persuade Abdou to take the child in. Amin and Abdul Latif are both Yemini émigrés. While Abdul Latif left Yemen to seek work, Amin has emigrated to pursue his religious studies that he could not achieve in his homeland. He has found Ethiopia to be "a wide open-place" where he can practice his faith more freely [41]. Amin finds contentment in exile and continues to live in seclusion preaching and helping those in need.

Feeling overjoyed and blessed, Abdul Latif embarks on a quest to save the child. He goes around seeking information about Abdou. Eventually he meets Saleh Saif, who owns a store in Sodest Kilo, and who knows Abdou very well. Abdul Latif asks Saleh to accompany him in order to talk Abdou into taking care of "his" child. Saleh seems reluctant, as he believes that Abdou would never acknowledge the child. The two men finally leave to see Abdou. On the way, Saleh ponders on which approach he would take in order to convince Abdou because sees Abdou as a tight person. The author provides a fresh, yet not unexpected, perspective on Abdou through Saleh's eyes. The author writes, "How many times had Saleh Saif seen Abdou fold up the newspapers in his shop without even thinking to read them? He never gave donations or attended community meetings. He lived in complete isolation" [47].Saleh's insight is momentous to understanding Abdou. It is apparent that not only has Abdou secluded himself from everybody and even his fellow émigrés, but also he has not given any financial contributions to support the revolutionary government.xx Abdou has not ever declared which side he supports. The fact that he isolated himself form any political involvement shows Abdou's unconcern to the war. Abdou's choice to dissociate himself from any political involvement is no surprise. Studies have shown that the person who is estranged is less likely to be a political activist. xxi $\mathrm{He}$ has been only concerned with his family. The war has led him to leave the most precious things in his life. The social progress that the revolutionists call for means nothing to Abdou. He has no sentiment toward the political conflict in his homeland. Abdou's indifference resonates with the struggle of his identity and sense of belonging.

Abdou is baffled when he sees Abdul Latif and Saleh get out of the car and head toward his store. He does not expect any kind of visitors. For years, he has lived in isolation. The two men are puzzled as well as they find no chairs in the store, nothing but a Abdou's bed and sacks of food. About this encounter, the author writes: "the two men fidgeted uncomfortably. The place was too stuffy...everything looked unusual. The store, though small, was filled with all sorts of goods piled in complete chaos. And the man who stood before them was an eccentric character, his black clothing dirty with oils and ghee and other things that had spilled on it" [49]. Not only the store is in chaos, Abdou seems to be in disarray as well. The filthy clothes and the lack of chairs suggest his remoteness. He neither dresses up nor makes his store neat and clean. An organized place may mirror person. However, because Abdou is only concerned with his customers who come only to buy, having a seating area seems unnecessary.

The condition of the store makes Abdul Latif uncomfortable. He forgets all that he has planned to say. He seems lost as Abdou stands in front of him. The narrator describes this moment masterfully; "[Abdul Latif] had a long introduction in his mind, which he now tried to recollect-Quranic verses and sayings of the Prophet, prayers for the man. But all of that flew out of his mind as he stood in front of Abdou, who tried to smile" [49]. It appears that total disarray reflects the current state of the meeting between Abdou and the two men. But in order to eliminate this tension, Abdul Latif decides to be blunt. In a harsh and strong voice, he says, "I've come to speak to you concerning your son" [49]. Abdul Latif's straightforward words manage to jolt Abdou. As he tries to respond, Abdul Latif bombards him with a tough criticism: "People know, and you've got to take your son and rear him. Isn't it forbidden... to leave him orphaned, living a life of loss?' [49]. When Abdou heard the word 'son,' the image of his son in Yemen has started to twirl in his mind. It appears that Abdou's family guides his thinking. However, as soon as he plays back Abdul Latif's words in his mind, he realizes how serious the matter is. He has to stop these accusations. Sarcastically he tells him that he is surprised that Abdul Latif has believed the prostitute's words. The author writes, "I thought you were thinker, but..."[50]. Not only Abdou's cynical tone irritate Abdul Latif, but the fact that he does not finish his sentence makes him more furious. The author depicts how Abdul Latif feels saying, "Blood boiled in his head. His face was bright red from the humiliation that tore at him" [50]. It seems that Abdou's main goal is use humiliation as a weapon in order to destroy Abdul Latif so his purpose of visit goes unproductive. Palshikar notes that humiliation makes the person inferior or deficient.xxii

Saleh realizes that being direct with Abdou does not help. Another approach is needed. So he tells Abdou, "We're from the same country, which makes us cousins. We are all Yemenis. If something hurts one of us, it hurts us all, so we came to you. We aren't here to call each other names, but to shake hands as brothers" [50]. Saleh tries to be wiser and rational. It appears that he wants to be the voice of reason through playing the tribal identity card. Naser Al-Hujelan notes about tribal Arabs, " the people of a tribe are linked to each other by tribal "ethos," meaning that members must 
support their own group". xxiii Saleh thinks that such introduction serves to control the discussion and eventually guide it to wanted results. Saleh's underlying message is that Abdou has done an inappropriate thing that would affect all Yemenis. However, Abdou's deed needs to be resolved peacefully.

The rationality of Saleh helps ease Abdou who immediately defends himself by saying, "I' $m$ the poor guy you had to talk to; why don't you go check on others?" [51]. Abdou thinks that his lack of authoritative voice in Sodest Kilo is what had made these two men come to him. He reasons that nobody goes to people with power even though they sleep with prostitutes. But Abdul Latif explains that others turn will come ultimately. Abdou looks hopeless, as he has not expected that Ta'atto's threat would reach a point where his fellow Yemenis confronts him. As he ponders on how Ta'atto has managed to exploit him in front of his people, he surprises the two men with his decision to go back to Yemen. Abdou's announcement leads to both surprise and laugh in the two men. The two men think Abdou has gone senseless. Abdul Latif exclaims, "You see! He's crazy; he said he'll return to Yemen. . He thinks it's paradise over there, that the Imam suddenly became a good and gentle ruler. Listen the situation in Yemen remains as it is. No one can live there. Trust me" [52]. Abdul Latif sees no future in Yemen - a belief that is apparent to everyone except Abdou. But Abdou is not concerned with the situation in Yemen. He explicitly records, "But I don't care...I want to go home, to farm my land and live with my wife and son" [52].

Abdou's above words reflect his eagerness to be with his family regardless of the political battle between the current leader, the Imam, and the revolutionary government. While this brutal conflict has been responsible for driving many out of the country and while many believe that life in Yemen is unbearable as the war remains active. There is no doubt that civil wars have many effects on civilian life. Jean Baker notes, "the lives of civilians - ordinary people in unusual times-[are not] removed from the events taking place on the battlefield, no matter how distant they may be."xxiv Not only the war affects families in Yemen, but also those who have emigrated trying to remove themselves from its cycles. Baker states, "besides these personal losses and the loneliness endured by women, children, and the old, the war [brings] political uncertainties."xxv Therefore Abdul Latif and many are skeptical about future in their homeland. Nevertheless, Abdou is a distinct case. The author presents a different kind of protagonist in the novella, one whose consciousness is fixed on his family's welfare, not the warfare. Even though Abdou's family lives with the war, and that Abdou is not immersed in warfare, there is a deep connection between them. Even if the war is inflicting the horrors upon people in Yemen, both want to live together. Perhaps the trauma of the war has transformed Abdou into someone else, someone having parts missing from his psyche. Abdou values his family. It is the most natural thing for anyone to value the family. But to Abdou, the world becomes a far more dangerous place without the family. Every moment Abdou has spent in Ethiopia is supposed to achieve significant results in his life. That is why Abdou has made it very clear to the two men that he does not care and that his only aspiration is: "I want to go home, to farm my land and live with my wife and son." Abdul Latif and Saleh doubt Abdou's decision to return but when he affirms that he has started getting rid of things in his store, the two men are silent. As they leave, Abdul Latif remarks, "God will not forget those who do good works" [53].

The whole meeting absorbs Abdou. In an important monologue, the author vividly provides another platform where readers are invited to observe Abdou's feelings, worries, and religious views. Abdou thinks:

They talk about good deeds, they, the scoundrels who get involved in all sorts of scandals, and no one says anything to them...but we, the poor, they count each breath we take. Good deeds: if the hajji [Abdul Latif] wanted to save the boy... why didn't he take him in? Why did he sentence me? Goddamn lust and pleasure; who told her to get pregnant? Oh God, I seek your forgiveness, but your servant is wretched. God created the child, and $\mathrm{He}$ is the great provider...Yes I could be his father, God knows, and He is the forgiving and the beneficent, and He will not take a poor man with a sin. Oh God, I'll perform hajj and repent for all my sins and will stay pious to the end of my life. Just help me out of this mess, oh God. [53]

Abdou discloses distress and resentment at the two men's perspectives. Evidently Abdou finds their logic preposterous. The above passage is crucial as it displays several scopes to Abdou's idiosyncratic system of beliefs. First, Abdou feels he is rather the victim, not the child. Because he lacks power and prestige in Ethiopia - the result of his long-term isolation-Abdou feels that people are taking advantage of him. Second, Abdou considers his voice to be representative of all helpless people that get victimized by those holding the position of power. The use of "we" in his language clearly demonstrates Abdou's tendency to speak in solidarity with the poor. Third, Abdou reasons that even if he has done a wicked deed, Abdul Latif and Saleh, and even others are in no position to judge him. Abdou shows his dissatisfaction over hypocrite people who are immersed in immoralities, yet they renounce others iniquities. If their goal is the child's life, and maintain human dignity, why don't they take the child themselves? Abdou assumes that Abdul Latif and Saleh pretend to be pious, but they are deceitful. He is not certain that he is the father especially that he there is no fatherly love towards the boy. Thus, Abdou feels no obligation to take the child. Finally, the passage exhibits how truthfully Abdou seeks atonement for his misdeeds. Syed Husain explains that repentance in Islam is considered "the most potent religious exercise for the preservation and promotion of man's moral health" [189]. Hence, Abdou sincerely seeks to make amends for his past bad deeds through performing Hajj. Abdou declares that he has done sins and asks God to redeem 
his misguided soul. Abdou's prayers show how he is engaged in sense of despondency and despair thinking. The aspiration to perform Hajj and the promise of loyalty signal Abdou's genuine desire to be born again, freed from the clutches of his past sins.

\section{The Case of Muwallads}

Abdul Latif feels disordered as whether or not he is now responsible for the child after Abdou's refusal to adopt him. Abdul Latif shares his confusion with his secretary who deep inside is thrilled at the dilemma is manager put himself in. The secretary's contentment over Abdul Latif's despair is his way to get back for all times Abdul Latif has offended him. Even though the secretary is a Yemeni émigré who has worked for him for a long time, Abdul Latif has frequently "made a fool of him in public" [56]. The text does not offer much help as explain this abuse. Perhaps Abdul Latif insults his secretary in order to show his control and power over his employees. The author adds more depth to They Die Strangers by involving another character, the secretary, to show the plight of Yemeni expatriates.

The story of the secretary is a fascinating one. He comes from mixed blood; his father is Yemeni and his mother is Ethiopian. The author writes, "The secretary's father dreamed of his homeland, of a future in Yemen, someday when it was 'liberated' from oppression...He wasn't stranger, despite being an expatriate. He had a country to go home one day. But his son the secretary was like a rootless tree; he was no on. Yes, no on" [46]. Because each parent comes from a different race, the secretary appears to have lost his identity. Anne Wilson states that mixed race people frequently inhabit "an ambiguity of social position."xxvi Because the secretary does not have a country to which he adheres, he is stranger, so much like the child alleged to be Abdou's. Evidently, the existence of biracial children seems to provoke sympathy in the secretary. The narrator describes this affinity the secretary feels with the child by writing, "he harbored no ill feelings toward this child who he had not seen. In fact, he loved the boy, for, like the boy, he had been born without a country, a stranger in a strange land" [56]. One can draw an analogy between the secretary and the child. Not only are they mixed race individuals, but they are also presented namelessly. The author does not give them names in an attempt to highlight the damage emigration causes. It is not about a particular character; it is about the effect of long-term emigration. The secretary is neither Yemeni nor Ethiopian. He is what people call a "half-breed." Apart from the stories he hears from his father, he cannot identify himself with Yemen. Because he was not born in Yemen, and has never seen it, he feels he does not belong to it.

The secretary decides to take the child in as a little brother because "they were in the same situation and belonged to the same people" and because "they were the lost ones who were stuck in the middle, pulled by both sides" [56]. The secretary's decision shocks Abdul Latif. But the secretary explicates his choice in a very important passage, “I don't want him to be stranger. Do you know what it means to be without roots? Well, I do. So, yes, he'll be my brother. Oh, if only all the half-breads could find a savior, if only they could decide to find an end to this labyrinth in which they're lost" [57]. Some sociologists look at the location of mixed race people as "marginal; caught in the crossfire of racial conflict."xxvii Through the secretary's voice, the author unequivocally exhibits how biracial people feel disconnected and alienated, and how a sense of connection emerges not with a country but rather within them. The secretary describes himself as being a savior sent to save a human soul from the brutality of life hoping others get this opportunity of finding other saviors. The secretary believes he and others like him are lost in an identity maze striving to find the right path. Until then, they remain unknown in this world. However, the secretary realizes this reality or at least his reality. But in his eyes, Abdul Latif and many Yemenis live in a myth as they talk endlessly about freeing their country but they never will. The secretary tells his manager, "You ran away. From here you will never do anything but shout at the top of your lungs...but you're just opening your mouths, and no one hears you but us..."[57].

While the secretary accepts his reality as a half-breed with no country belonging, Yemenis, like Abdul Latif, are delusional. They think they contribute to the process of their country's liberation but they produce nothing but words. The secretary's perspective angers Abdul Latif who indignantly objects, "We work here to feed our people back home; we migrated to save our country" [57]. But the secretary believes that Yemenis migrated not because they wanted to liberate their country but rather because they were afraid. He sarcastically says "You escaped from the ghost of the Imam...if you really wanted to liberate your country, why did you get married and have children? I tell you frankly, you'll never be the ones to liberate the country. If it is liberated, it will be by those who stayed there, or perhaps by us" [57-58]. The secretary's reasoning is appealing. If Yemenis want freedom, they ought be pursuing it in their homeland not in Ethiopia. However, Abdul latif thinks they are doing the right thing by emigrating and sending money. If not, their families would agonize. The road to liberation starts with giving Yemenis back home tools to survive. Thus, Abdul Latif feels that by providing financial support émigrés are actively engaging in their country fight against the Imam's oppression.

\section{Seeking Redemption and the Collapse of a Dream}

The news that the secretary is adopting the child has spread to people in Sodest Kilo. Abdou is very pleased as he got out of the disarray. Abdou thinks now about his dream of return - seeing his wife, son and his grandson, his house, and land. He pictures how people in his village would praise Abdou and how "he was a man of worth, real worth" [59]. 
These images bring ecstasy to him. Abdou thinks all the fuss about the child was merely an attempt from his fellow émigrés to make him stay. Even Amin once told him " many emigrants preferred to emigrate again rather than remain at home" and "some of them lost everything in courts and conflicts" [60]. But nothing can stop Abdou from returning home. The narrator says, "But he would not go to courts to fight with anyone. He was just a simple human being who wanted to live quietly, worshiping his God and sowing his land. His entire reason for emigrating was so that one day he could go back to his village, work his father's land with his own two hands, and water it with his sweat" [60]. Abdou feels others are jealous of him because he is thrilled to go back for they do not know that Abdou's home is with his family and land. After Abdou closes his store and before he goes to sleep, he continues to dream about his return. Pictures twirl in his head of women, men, and children admiring his life and his self-worth. Because the night is cold, Abdou lights his kerosene stove to warm himself.

In the morning, customers wait for him to open the store. Abdou is late which makes the customers suspect he is either dead or seriously ill. Suddenly, the sound of painful sighs comes from inside the store. The customers call for help and Abdou is taken to a hospital looking in an agonizing shape. The author writes, "He was faint; his eyes bulged; his lips were pressed tightly to each other, as if he didn't want to talk, or as if he had suffered some terrible torture" [63]. Such a painful image the author presents to show Abdou's end. It turns out that Abdou forgot to turn his stove off leading him to inhale a huge amount of carbon dioxide while sleeping. At the hospital, the doctor, who looked after Abdou before his death, engages in a momentous discussion with his nurse who has known Abdou. The nurse tells her doctor that those migrants leave their homes and families to "chase after living" [64]. The doctor responds, " a nation that emigrates from its land is a nation of traitors" [64]. Similar to the secretary's standpoint, the doctor believes that people should not leave their home in search of material success. They should stay in their homeland and endure what others are undergoing.

But the choice to remain under poverty and political uncertainty is a tough one. Mohammed Saad Al-Jumly notes that during that period (the 1960's) instability plagued the country as well as poverty forcing thousands to leave their homeland.xxviii Therefore, even though Abdou is dead, the narrator speaks on his behalf in attempt to defend Abdou's dream, "unfortunately Abdou Said could not hear this conversation [between the doctor and nurse]. If he could, he would have opened his eyes, amazed. What were these crazy people talking about? He would have told them of the fabulous world of his dreams, the one that has become his alone and forever. It was better than anything they could ever hope to create" [64]. Through these lines, the author endeavors to keep Abdou's dream alive. Even if he is gone, his aspiration remains eternal. Abdou's funeral is simple. People gather to bade their farewell. The secretary brings his recently adopted child to the funeral and in a critical voice, he tells Abdul Latif, "you know when he died he left nothing behind. A woman deserted for years there, a son he didn't know about, a land to which he didn't offer a drop of his blood. He died like a stranger, like hundreds of Yemenis die in other lands. As for this grave-it's not his. It's not his land; it belongs to other people, to the Ethiopians... Oh God, we are such strangers! [65]. The secretary believes that Abdou has dedicated his life to nothing. Abdou left his wife, son, father, and land and struggled to maintain his links with them. He worked constantly hoping one day he would return as a wealthy man. But he could not. Moreover, in his sojourn, he did not assimilate. Weir notes, "His obsession with his goals makes him shun any relationships that might enmesh him in the local community, including those with Yemenis."xxix Abdou's plan to return fails. He dies as a stranger in a stranger land. Even the grave is not his. The author attempts to show how an émigré who chases materialistic goals and abandons his ideals collapses and dies unknown.

In summation, Abdul-Wali attempts in They Die Strangers to create an intriguing approach to the subject of immigration. Weir notes out, "It [They Die Strangers] dwells on the negative aspects of long-term emigration: the anguish of long separations from families and homeland, the loneliness and moral hazards of living in an alien cultural, and the tension between the immigrant's desire to assimilate in the host country and yearning to return."xxx Within the layers of these aspects, readers are meant to recognize different kinds of trauma. For Abdou, the original traumatizing event is his long estrangement from everything he loves. For the secretary, it is the loss of identity in the middle of political struggle. For Abdul Latif and many Yemeni immigrants, the trauma resides in their fight against injustice and oppression. It is almost as everybody is suffering in They Die Strangers. Even Amin, who has been striving to preserve his closeness to God, struggles in his detachment from the world. But the trauma of leaving is the crucial one. Abdul-Wali frames the story around departure. Yeminis leave their homeland due to the harsh conditions of life in it. Their departure has brought a vision of loss - families, lands, identities, ideals, religion, and mores. The irony is in their dreams in which the author merges two worlds, reality and delusion. However, apart from the secretary, it seems that every one cannot accept his reality.

\section{REFERENCES}

[1] Al-Jumly, Mohammed Saad, and J. Barton Rollins. "Emigration and the Rise of the Novel in Yemen." World Literature Today 71.1 (1997): 39-46

[2] Al-Hujelan, Naser S. Worldviews of the Peoples of the Arabian Peninsula a Study of Cultural System. Bloomington, Indiana.: Indiana U, 2008. Print.

[3] Al-Wali, Muhammad Abdul, Abu Bakr Ahmad. Baqadir, and Deborah S. Akers. They Die Strangers. Austin: Center for Middle Eastern Studies, the U of Texas at Austin, 2001. Print. (Introduction 10) 
[4] Baker, Jean. "The Civilian Experience in the Civil War." National Parks Service. U.S. Department of the Interior, n.d. Web. 24 Jan. 2015.

[5] Black, Dora. "Bereavement in Childhood." BMJ : British Medical Journal. British Medical Journal, 21 Mar. 1998. Web. 31 Dec. 2014.

[6] ---. "The Bereaved Child." Journal of Child Psychology and Psychiatry 19.3 (1978): 287-92. Web.

[7] Chelala, Silvia. "The Stories of the Forgotten." Al Jadid Magazine. Al Jadid Magazine, Summer 2002. Web. 20 Feb. 2015.

[8] "Despite Fast Growth, Ethiopia Still Plagued by Poverty." VOA. Voice of America, 7 Dec. 2012. Web. 16 Dec. 2014.

[9] "The DNA Story." The DNA Story. N.p., n.d. Web. 14 Jan. 2015.

[10] Duffin, Claire. "Why Do We Cry Tears of Joy?" The Telegraph. Telegraph Media Group, 12 Nov. 2014. Web. 06 Jan. 2015.

[11] Fischer, Claude S. "On Urban Alienations and Anomie: Powerlessness and Social Isolation." American Sociological Review 38.3 (1973): 311 . Web.

[12] Foner, Nancy. "The Immigrant Family: Cultural Legacies and Cultural Changes." International Migration Review 31.4 (1997): 961-975 and Garcia Coll, Cynthia, and Katherine Magnuson. "The Psychological Experience of Immigration: A Developmental Perspective." Immigration and the Family. Ed. Alan Booth, Ann Crouter, and Nancy Landale. Mahwah, NJ: Lawrence Erlbaum, 1997. 91-132. Print.

[13] Gatrad, Abdul Rashid, and Aziz Sheikh. "Hajj: Journey Of A Lifetime." BMJ: British Medical Journal 330.7483 (2005): 133-37.

[14] Hobart, Charles W. "Types of Alienation: Etiology and Interrelationships." Canadian Review of Sociology/Revue Canadienne De Sociologie 2.2 (1965): 92-107. Web.

[15] Holmes, William. "'The Theory of Alienation as Sociological Explanation: Its Advantages and Limitations." Sociology 10 (1976): 207-24. Print.

[16] "Khat Chewing in Yemen: Turning over a New Leaf." WHO. WHO, Oct. 2008. Web. 23 Dec. 2014

[17] Lystad, Mary Hanemann. "Social Alienation: A Review of Current Literature." The Sociological Quarterly 13.1 (1972)

[18] MacDonald, George, and Nora S. Unwin. The Princess and Curdie. New York: Macmillan, 1954. Print.

[19] Mohammed, Farhan. "Crisis of Identity in Mohammed Abdul-Wali's They Die Strangers." Thesis. Hodeidah University, 2009 (Chapter 2).

[20] "North Yemen Civil War (1962-1970)." GlobalSecurity.org, n.d. Web. 20 Jan. 2015.

[21] Palshikar, Sanjay. "Understanding Humiliation." Economic and Political Weekly 40.51 (2005): 5428

[22] Peace and War: United States Foreign Policy, 1931-1941. Washington, D.C.: U.S. Govt. Print. 1942.

[23] Rose, Arnold M. "Alienation and Participation: A Comparison of Group Leaders and the "Mass"" American
Sociological Review 27.6 (1962): 834-38.

[24] Whitehurst, Robert. "Extramarital Sex: Alienation or Extension of Normal Behavior." Extramarital Relations. Ed. G. Neubeck. New Jersey: Prentice-Hall, 1969. Print.

[25] Wilson, Anne. "'Mixed Race' Children in British Society: Some Theoretical Considerations." The British Journal of Sociology 35.1 (1984): 46.

\section{Notes}

i Chelala, Silvia. "The Stories of the Forgotten | Al Jadid Magazine." The Stories of the Forgotten $\mid$ Al Jadid Magazine. Aljadid, Summer 2002. Web. 15 Dec. 2014

ii They Die Strangers was first published in Arabic in 1971 by Alsharara newspaper. In 2002, the Center for Middle Eastern Studies at the University of Texas at Austin published the English translation of the novella.

iii See "Despite Fast Growth, Ethiopia Still Plagued by Poverty." VOA. Voice of America, 7 Dec. 2012. Web. 16 Dec. 2014.

iv Mohammed. "Crisis of Identity in Mohammed Abdul-Wali's They Die Strangers." Thesis. Hodeidah University, 2009 (Chapter 2).

v Lystad, Mary Hanemann. "Social Alienation: A Review of Current Literature." The Sociological Quarterly 13.1 (1972): 90

vi See Whitehurst, Robert. "Extramarital Sex: Alienation or Extension of Normal Behavior." Extramarital Relations. Ed. G. Neubeck. New Jersey: Prentice-Hall, 1969. Print.

vii Hobart, Charles W. "Types of Alienation: Etiology and Interrelationships." Canadian Review of Sociology/Revue Canadienne De Sociologie 2.2 (1965): 92-107. Web.

viii Qat or khat is a plant grown in many parts in the Arabian Peninsula and largely in Yemen. Qat chewing releases chemicals that give the chewer a mild high that some say is comparable to drinking strong coffee. See "Khat Chewing in Yemen: Turning over a New Leaf." WHO. WHO, Oct. 2008. Web. 23 Dec. 2014

ix Fischer, Claude S. "On Urban Alienations and Anomie: Powerlessness and Social Isolation." American Sociological Review 38.3 (1973): 311. Web.

x Black, Dora. "Bereavement in Childhood." BMJ : British Medical Journal. British Medical Journal, 21 Mar. 1998. Web. 31 Dec. 2014.

xi ---. "The Bereaved Child." Journal of Child Psychology and Psychiatry 19.3 (1978): 287-92. Web.

xii See Foner, Nancy. "The Immigrant Family: Cultural Legacies and Cultural Changes." International Migration Review 31.4 (1997): 961-975 and Garcia Coll, Cynthia, and Katherine Magnuson. "The Psychological Experience of Immigration: A Developmental Perspective." Immigration and the Family. Ed. Alan Booth, Ann Crouter, and Nancy Landale. Mahwah, NJ: Lawrence Erlbaum, 1997. 91-132. Print.

xiii Duffin, Claire. "Why Do We Cry Tears of Joy?" The Telegraph. Telegraph Media Group, 12 Nov. 2014. Web. 06 Jan. 2015.

xiv Holmes, William. "'The Theory of Alienation as Sociological Explanation: Its Advantages and Limitations." Sociology 10 (1976): 207-24. Print.

xv MacDonald, George, and Nora S. Unwin. The Princess and Curdie. New York: Macmillan, 1954. Print. 73

xvi Chelala, "The Stories of the Forgotten"

xvii "The DNA Story." The DNA Story. N.p., n.d. Web. 14 Jan. 2015.

xviii In Islam, Hajj is the pilgrimage to the holy city of Mecca (or Makkah) in Saudi Arabia, which every adult male and female, who is physically and financially capable, must make at least once in his or her lifetime. See Gatrad, Abdul Rashid, and Aziz Sheikh. "Haji: Journey Of A Lifetime." BMJ: British Medical Journal 330.7483 (2005): 133-37.

xix Palshikar, Sanjay. "Understanding Humiliation." Economic and Political Weekly 40.51 (2005): 5428

xx In 1962, a rebellion of revolutionary forces (the liberals) led by the army overthrew the new appointed leader (the royalists) and proclaimed the Yemen Arab Republic. The royalists with financial and material support from external sources, fought against the republican forces. Money was needed to assist the republican forces in their fight against the royalists. For more information, see "North Yemen Civil War (1962-1970)." GlobalSecurity.org, n.d. Web. 20 Jan. 2015.

xxi Rose, Arnold M. "Alienation and Participation: A Comparison of Group Leaders and the "Mass"' American Sociological Review 27.6 (1962): 834-38.

xxii Palshikar, Sanjay. "Understanding Humiliation." Economic and Political Weekly 40.51 (2005): 5428

xxiii Al-Hujelan, Naser S. Worldviews of the Peoples of the Arabian 
Peninsula a Study of Cultural System. Bloomington, Indiana.: Indiana U, 2008. Print. 91

xxiv Baker, Jean. "The Civilian Experience in the Civil War." National Parks Service. U.S. Department of the Interior, n.d. Web. 24 Jan. 2015.

$\mathrm{xxv}$ Ibid

xxvi Wilson, Anne. "'Mixed Race' Children in British Society: Some Theoretical Considerations." The British Journal of Sociology 35.1 (1984): 46.

xxvii Ibid 46

xxviii Al-Jumly, Mohammed Saad, and J. Barton Rollins. "Emigration and the Rise of the Novel in Yemen." World Literature Today 71.1 (1997): $39-46$

xxix Al-Wali, Muhammad Abdul, Abu Bakr Ahmad. Baqadir, and Deborah S. Akers. They Die Strangers. Austin: Center for Middle Eastern Studies, the U of Texas at Austin, 2001. Print. (Introduction 10)

xxx Ibid 11 